\title{
Audio Selections
}

Audio Files that accompany this book may be found on the UC Press website. See Note on the Text, p. xix

\section{CHAPTER 3: EXPERIENCING MUSICAL CONCEPTS: FOCUS ON LATIN AMERICA}

Sound Link 3.1. Guitarrón.

Sound Link 3.2. Vihuela.

Sound Link 3.3. Charango. "Alegría," by Quechua musicians. Instruments and Music of Indians of Bolivia (Smithsonian Folkways, FW 01412, 1962, 2004).

Sound Link 3.4. Berimbau. Various artists. The Music of Capoeira: Mestre Acordeon (Smithsonian Folkways, FW04332, 1985, 2004).

Sound Link 3.5. Conch shell trumpets. Q'eros authorities. Mountain Music of Peru, vol. 1 (Smithsonian Folkways, SFW40020, 1991).

Sound Link 3.6. Siku. Aymara musicians. Instruments and Music of Indians of Bolivia (Smithsonian Folkways, FW 01412, 1962, 2004).

Sound Link 3.7. Agogô.

Sound Link 3.8. Cowbell.

Sound Link 3.9. Pandeiro.

Sound Link 3.10. Caxixi.

Sound Link 3.11. Güiro.

Sound Link 3.12. Maracas.

Sound Link 3.13. Bongos.

Sound Link 3.14a. Conga.

Sound Link 3.14b. Conga in guaguancó.

Sound Link 3.15. Timbales.

Sound Link 3.16. Claves.

Sound Link 3.17. Major scale, played on the piano.

Sound Link 3.18. Minor scale, played on the piano.

Sound Link 3.19. Chromatic scale, played on the piano.

Sound Link 3.20a. Andalusian-Phrygian scale, played on the guitar.
Sound Link 3.20b. Another Andalusian-Phrygian scale, played on the guitar.

Sound Link 3.20c. Andalusian-Phrygian sonority, played on the guitar.

Sound Link 3.21. Pentatonic scale, played on the piano.

Sound Link 3.22. Tritonic scale, children's taunt.

Sound Link 3.23. Major scale and a I chord, played on the guitar.

Sound Link 3.24. Minor scale and a i chord, played on the piano.

Sound Link 3.25. Major scale and a IV chord, played on the guitar.

Sound Link 3.26. V chord, in a major scale, played on the guitar.

Sound Link 3.27a. I-IV-V-I chord progression, basic strum, played on the guitar.

Sound Link 3.27b. I-IV-V-I chord progression, alternative strum, played on the guitar.

Sound Link 3.27c. I-IV-V-I chord progression, broken chords, played on the guitar.

Sound Link 3.27d. I-IV-V-I chord progression, played on the piano.

Sound Link 3.28. I-V-I-V-I chord progression, played on the piano.

Sound Link 3.29. Authentic cadence, played on the piano.

Sound Link 3.30. Half cadence, played on the piano.

Sound Link 3.31. Deceptive cadence, played on the piano in a familiar song.

Sound Link 3.32. Sequence, played on the piano.

Sound Link 3.33. A familiar triple-meter song, played on the piano.

Sound Link 3.34. The same familiar song in duple meter, played on the piano. Arr. David Gregory Byrne.

Sound Link 3.35. The same familiar song, syncopated, played on the piano. Arr. David Gregory Byrne. 
Sound Link 3.36. The same familiar song with some improvisation, played on the piano. Arr. David Gregory Byrne.

Sound Link 3.37. The same familiar song with more improvisation, played on the piano. Arr. David Gregory Byrne.

Performers: guitarrón, Jesús Rico; vihuela, Robert Blake; percussion, Chris Froh (with Stephen Bingen in Sound Link 3.14b); guitar, Jonathan Favero; piano, Carol A. Hess.

\section{CHAPTER 4: EXPERIENCING LATIN AMERICAN RELIGIOUS MUSIC}

4.1. “Babalú Ayé: Oru para Todos los Santos," part 2. San Cristóbal de Regla Gourd Ensemble. Sacred Rhythms of Cuban Santería (Smithsonian Folkways SF 40419, 1995).

4.2. “Salve Regina.” Edmundite Novices. Gregorian Chants Sung by the Edmundite Novices (Smithsonian Folkways FR 8954 1961, 2007).

4.3. "Music and Song for Sheep." Domingo Chompi and Luisa Sera Chompi. Mountain Music of Peru, vol. 1 (Smithsonian Folkways SF40020; 1966, 1991).

4.4. "Credo," from Missa Ave Regina Caelorum. The Sixteen, director Harry Christophers. Streams of Tears (The Voices of the Classic, 2008).

4.5. Shaman Chant no. 11. Lola Kiepja. Selk'nam Chants of Tierra del Fuego, Argentina (Smithsonian Folkways FE 4176 1972, 2007).

4.6. "Kol nidrei." Cantor Abraham Brun. Cantorials for the High Holidays (Smithsonian Folkways Archival FW 6940 1956, 2006).

\section{CHAPTER 5: EXPERIENCING LATIN AMERICAN MUSIC AND IDENTITY}

5.1. "Sin ti." ;Ayombe! The Heart of Colombia's Música Vallenata. Ivo Díaz, singer, and ensemble (Smithsonian Folkways Recordings SFW CD 40546, 2008).

5.2. "Cholo orgulloso." La Pallasquinita, singer, and ensemble. Huayno Music of Peru, vol. 1 (Arhoolie Records CD 320, 1989).

5.3. Cordon: Candombe lento. Various artists. Uruguay: Tambores del Candombe (Musique du Monde, Buda Records 92745-2, 1999).

5.4. "Piririta." Alejo Benítez. Maiteí América: Harps of Paraguay (Smithsonian Folkways SFW CD 40549, 2009).
5.5. "Los trece." Marimba Chapinlandia. Chapinlandia: Marimba Music of Guatemala (Smithsonian Folkways SFW CD 40542, 2007).

5.6. "Ahora sí." Tito Matos and Viento de agua. Viento de Agua Unplugged: Materia prima. (Smithsonian Folkways SFW CD 40513, 2004).

5.7. "Malambo," from Estancia. Gustavo Dudamel and Simón Bolívar Venezuelan Youth Symphony. iFiesta! (Deutsche Grammophon 028947774570 GH, 2008).

5.8. “Aquarela do Brasil." Francisco Alves (singer), ensemble. Ary Barroso: Aquarelas, vol. 1 (historic recording, reissued by Instituto Cultural Cravo Albin).

5.9. “No!” Willie Colón (singer) and ensemble. Willie Colón: Mis Favoritas (Sony US Latin CD 8869 770886 2, 2010).

5.10. “Las abajeñas." Mariachi Cobre. Mariachi Cobre (Kuckuck Schallplatten CD 11105-2, 1995).

5.11. “Llanero, sí soy llanero." Joropo Music from the Orinoco Plains of Colombia (Smithsonian Folkways CD 40515, 2004).

\section{CHAPTER 6: EXPERIENCING LATIN AMERICAN MUSIC THROUGH THE BODY}

6.1. Ladainha: Rei Zumbi dos Palmares; Chula: Rei Zumbi dos Palmares; Rei Zumbi dos Palmares: Santa Barbara. Grupo de Capoeira Angola Pelourinho; Capoeira Angola Pelourinho (Smithsonian Folkways SFW40465, 1995).

6.2a. "El choclo." Sexteto Mayor. 50 Best Tangos (EMI, 2011).

6.2b. "Adios muchachos." Carlos Gardel, singer. Carlos Gardel: Sus 40 Tangos Más Famosos (Suramusic S.R.L. FK 026, 2003).

6.3. Yaqui Deer Dance. Male Yaqui singers and ensemble. Indian Music of Mexico (Smithsonian Folkways FE 4413 1952, 2006).

6.4. Cueca. Olga Guzmán, singer, harp. Chile: HispanoChilean Métisse: Traditional Music (Smithsonian Folkways Archival UNES 08001, 2014).

6.5. Vals venezolano no. 1. Elliot Frank, guitar. Elliot Frank: South American Guitar Music (ACA Digital Recordings 20049, 2006).

6.6. “Así lo grita Totó." Los Gaiteros de San Jacinto. Un fuego de sangre pura (Smithsonian Folkways Recordings CD 40531, 2006).

6.7. "La bamba." José Gutiérrez y Los Hermanos Ochoa. La Bamba: Sones Jarochos from Veracruz (Smithsonian Folkways CD 40505, 2003). 
6.8. "America," from West Side Story. West Side Story: Original Motion Picture Soundtrack (Sony Masterworks, 1965).

\section{CHAPTER 7: EXPERIENCING LATIN AMERICAN MUSIC AND POLITICS}

7.1a. "Guantanamera." Pete Seeger, singer and guitarist. Headlines and Footnotes: A Collection of Topical Songs (Smithsonian Folkways Recordings CD 40111, 1995).

7.1b. "Guantanamera." Pete Seeger, singer and guitarist. The Essential Pete Seeger (Sony Legacy 475 1598, 2005). Note that there is no online audio guide for this selection; rather, it is a complement to selection 7.1a.

7.2. “Tragedia de la Plaza de Tres Culturas." Judith Reyes, singer, guitars. Mexico: Days of Struggle (Smithsonian Folkways Archives CD PAR01012, 2006).

7.3. "Zelão." Zelia Barbosa, singer, and ensemble. Brazil: Songs of Protest (Smithsonian Folkways MFS 717, 2006).

7.4. "Aquí me quedo." Víctor Jara, singer and guitarist. Manifiesto (Wea International CD 87610, 2003).

7.5. Sensemayá. Mexico City Philharmonic; Fernando Lozano, director. Mexico City Philharmonic Orchestra and Fernando Lozano (Forlane, 2009).

\section{CHAPTER 8: BUT IS IT ART? EXPERIENCING} LATIN AMERICAN CLASSICAL MUSIC

8.1. "Venus en los montes." Judith Malafronte (Venus), Andrew Lawrence-King (harp). La púrpura de la rosa (Deutsche Harmonia Mundi 05472 77355-2, 1999).

8.2. “Le Printemps." Clara Rodríguez, pianist. Music of Teresa Carreño (Nimbus NI6103, 2009).

8.3. Sinfonía India. London Symphony Orchestra, Eduardo Mata, director; Carlos Chávez: The Complete Symphonies (Vox CDX 5061, 1992).

8.4. Bachianas brasileiras no. 5, mvt. 1. Kiri Te Kanawa, singer; cello ensemble. Kiri Te Kanawa: Canteloube, Songs of the Auvergne/Villa-Lobos, Bachianas brasileiras no. 5 (Decca 411-730 1DH, 1995).

8.5a. Epilogue, movement 4 of Canciones de Jara. Roberto Díaz, violist; Symphony in C, Stillian Kirov, director [permission of the composer, Ricardo Lorenz].

8.5b. “Canción del Minero." Víctor Jara, singer and guitarist. Habla y canta (Sucesión Víctor Jara, B01FFB7DYY, 1972, 2016). Note that there is no online audio guide for this selection; rather, it is a complement to selection $5 \mathrm{a}$.

8.6. Nic Quetza Tohuehueuh. UC Davis Early Music Ensemble, Will Cooper, director, 2014 [permission of the composer, Gabriel Bolaños]. 
